\title{
PHYTOCHEMICAL COMPOUNDS AND ANTIOXIDANT ACTIVITY OF YELLOW VELVETLEAF FRUIT (LIMNOCHARIS FLAVA) EXTRACT
}

\section{ACE BAEHAKI*, SHANTI DWITA LESTARI, NORYATI SIREGAR}

Study Program of Fisheries Product Technology, Faculty of Agriculture, Sriwijaya University, Indralaya, South Sumatera, Indonesia. Email: abaehaki.unsri@gmail.com

Received: 21 October 2019, Revised and Accepted: 10 December 2019

\section{ABSTRACT}

Objective: The purpose of this research was to observe the content of phytochemical compound and antioxidant activity of yellow velvetleaf fruit (Limnocharis flava) extract.

Methods: Research consisted of several stages, including sampling, sample preparation, sample extraction, calculation of yield extract, phytochemical analysis (flavonoids, steroids, alkaloids, saponins, and triterpenoids), and antioxidant activity assessment using 2',2'-diphenyl-1-picrylhydrazyl and iron-reducing power method.

Results: The n-hexane and methanol extract contained flavonoids, saponins, and triterpenoids, while flavonoids and triterpenoids were detected on ethyl acetate extract. The IC ${ }_{50}$ of yellow velvetleaf extract with n-hexane, ethyl acetate, and methanol was 3321.67 ppm, 1439.24 ppm, and 96.0 ppm, respectively. The methanol extract had the highest iron-reducing power with the average absorbance of 0.588 followed by the ethyl acetate extract with the average absorbance of 0.195 and n-hexane extract had lowest with the average absorbance of 0.171 .

Conclusion: The best solvent to extract the yellow velvetleaf and have highest antioxidant activity was methanol solvent.

Keywords: Antioxidant, Phytochemical, Reducing ability, Yellow velvetleaf fruit.

(C) 2020 The Authors. Published by Innovare Academic Sciences Pvt Ltd. This is an open access article under the CC BY license (http://creativecommons. org/licenses/by/4. 0/) DOI: http://dx.doi.org/10.22159/ajpcr.2020.v13i2.36136

\section{INTRODUCTION}

Natural antioxidants have been found to be useful not only in the body defense system against reactive oxygen species but also in managing the oxidative stress caused by several diseases such as diabetes [1]. A number of plants have significant antioxidant activity due to the presence of certain natural products responsible for scavenging the excess free radicals from the system [2]. Research on bioactive compounds that have been carried out in aquatic plants was swamp plant (Nymphaea stellata, Nelumbo nucifera, and Eleocharis dulcis) and seagrasses (Halodule uninervis and Halodule pinifolia) [2-7].

Yellow velvetleaf (Limnocharis flava) is a plant that grows in bogs or muddy pool that much water. Yellow velvetleaf ( $L$. flava) is native to tropical and subtropical regions of America [8]. Leaves and flowers of yellow velvetleaf were efficacious as an appetite enhancer. Besides consumed, yellow velvetleaf used as environment (eliminating pollution in the water) and livestock [9]. Fresh yellow velvetleaf leaves contained total carotenoid $(219.01 \mu \mathrm{g} / \mathrm{g})$, protein $(22.96 \%)$, fat (7.95\%), ash (12.4\%), water content (91.76\%), and fiber (11.93\%) [10]. Yellow velvetleaf has high content of total carotenoid and bioactive compounds [11].

\section{METHODS}

\section{Preparation of extraction}

Swamp plants (yellow velvetleaf) before extraction are carried out beforehand, the preparation is done, namely: Swamp plants are washed with running water to remove foreign objects (stones, sand, seashells, and so on). Then, drying is done using sunlight for 4 days until the water content is $<10 \%$.

\section{Extraction}

Yellow velvetleaf ( L. flava) which has been prepared then extraction process is carried out. The extraction method carried out in this study is a multilevel extraction method. Stage 1 is done with n-hexane (nonpolar) solvent for $2 \times 24 \mathrm{~h}$. Stage 2 is carried out with ethyl acetate (semipolar) solvent for $2 \times 24$ h. Stage 3 is done with $70 \%$ ethanol solvent (polar) for $2 \times 24 \mathrm{~h}$.

The extraction stage was as follows: Swamp plant powder was weighed $250 \mathrm{~g}$ and put into Erlenmeyer, then a solvent was added until the final volume reached $1000 \mathrm{ml}$ with a ratio of $1: 5(\mathrm{w} / \mathrm{v})$, extracted by multilevel maceration using $n$-hexane (nonpolar) solvent, ethyl acetate (semipolar), and $70 \%$ ethanol (polar), respectively, for $2 \times 24 \mathrm{~h}, 3$ times the extraction. The extract obtained from all three types of solvent was concentrated with rotary evaporator, except ethyl acetate solvent. Extracts with ethyl acetate solvent are dried in a fume hood.

\section{Phytochemical test}

Phytochemical tests were carried out to determine whether there were bioactive components found in swamp plants (yellow velvetleaf). Phytochemical analysis carried out included flavonoids, alkaloids, triterpenoids and steroids, and saponins. The analytical method used is based on Harborne [12].

\section{Antioxidant activity}

Testing of antioxidant activity using the 2',2'-diphenyl-1-picrylhydrazyl (DPPH) method refers to Hanani et al. [13], namely: DPPH solution was made with a concentration of $1 \mathrm{mM}(0.0197 \mathrm{mg}$ DPPH in $50 \mathrm{ml}$ of methanol). The crude extract of water hyacinth flower is made in various concentrations, namely, $50 \mathrm{ppm}, 100 \mathrm{ppm}, 250 \mathrm{ppm}, 500 \mathrm{ppm}$, and $1000 \mathrm{ppm}$. The methanol solution without extract is used as a blank. The extract solution and blank solution were made; each of $4 \mathrm{ml}$ was reacted with $1 \mathrm{ml}$ of DPPH $1 \mathrm{mM}$ solution in a test tube. The mixture was homogenized with vortex and then incubated at $37^{\circ} \mathrm{C}$ for $30 \mathrm{~min}$, then measured the absorbance using a spectrophotometer at a wavelength of $517 \mathrm{~nm}$. The results of measuring the absorbance of the solution are used to calculate the percentage of radical capture and $\mathrm{IC}_{50^{\circ}}$. 
The percentage of radical capture is the ratio between the difference between the absorbance of the blank and the absorbance of the sample with the absorbance of the blank. The radical capture percentage is used to determine the percentage of resistance of a material made to free radical compounds. The radical capture percentage is calculated by the following formula:

$\%$ inhibition="Ab-As" /"Ab" $\times 100 \%$

Description:

$\%$ inhibition=Percentage of radical capture

$\mathrm{Ab}=$ Blank absorbance

As=Sample absorbance.

\section{RESULTS AND DISCUSSION}

\section{The phytochemical screening}

Phytochemical compound of yellow velvetleaf fruit ( L. flava) listed in Table 11.

Table 1 shows the $\mathrm{n}$-hexane and methanol extract contained flavonoids, saponins, and terpenoids, while flavonoids and terpenoids were detected on ethyl acetate extract. Flavonoids are active compounds belonging to the type of antioxidant intermediates, which act as hydrophilic and lipophilic antioxidants [14]. Flavonoids as benzo$\gamma$-pyrene derivatives have many uses in addition to their primary function as additives to increase resistance and decrease the capillary permeability of the blood. Other effects of flavonoids are very varied on many organisms and these effects may explain why flavonoidcontaining plants can be used in medicine. Flavonoids can serve as antiviral, allergic, antimicrobial, and antioxidants to control free radicals that can cause tumors. Flavonoids are antioxidants that play a role in protecting lipophilic antioxidants to strengthen cellular antioxidants [15]

Saponin is a surface-active compound and is like a soap. Saponins can be detected based on their ability to form foam and blood cell hemolysis. Saponins are triterpene and sterol glycosides that have been detected in over 90 plant tribes [12]. Triterpenoid compounds found in high plants are phytosterols consisting of sitosterol ( $\beta$-sitosterol), stigmasterol, and cholesterol. Terpenoid compounds can be used for treatment and therapy [16]. Triterpenoids are terpenoid groups that have potential as antimicrobials. In addition, this compound is widely used to cure skin diseases.

\section{Antioxidant activity}

Antioxidant might also be employed in preventing oxidation reactions (such as lipid peroxidation) that lead to deterioration of foods and foodstuffs [17]. Methanol extract has strong antioxidant activity because $\mathrm{IC}_{50}$ value obtained from methanol extract is worth between 50 and $100 \mathrm{ppm}$ while ethyl acetate and n-hexane extract have very weak antioxidant activity because IC $_{50}$ value obtained $>200 \mathrm{ppm}$, this is thought to be caused by more methanol extract many compounds of phenolic derivatives such as tannins and flavonoids.

Antioxidant activities (DPPH method) of yellow velvetleaf fruit (L. flava) shown in Table 2 and reduction power depicted in Fig. 1.

The results of antioxidant activity test (Table 2) showed that n-hexane, ethyl acetate, and methanolic extract of yellow velvetleaf fruits had the $\mathrm{IC}_{50}$ values following the order of $3321.67 \mathrm{ppm}, 1439.24 \mathrm{ppm}$, and $96.0 \mathrm{ppm}$. The results of the reduction test of yellow velvetleaf fruit extract (L. flava) are shown in Fig. 1.

Fig. 1 shows that the antioxidant activity test with reduction power test showed that the methanol extract had the highest reduction power at a concentration of $1000 \mathrm{ppm}$, which was equal to 1.402 , followed by the ethyl acetate extract having the highest reduction power at a concentration of $1000 \mathrm{ppm}$, which was 0.229 and n-hexane extract has the highest reduction power at a concentration of $1000 \mathrm{ppm}$,
Table 1: Phytochemical compound of yellow velvetleaf fruit (Limnocharis flava) extract

\begin{tabular}{llll}
\hline Phytochemical compounds & \multicolumn{2}{l}{ Solvent } & \\
\cline { 2 - 4 } & N-hexane & Ethyl acetate & Methanol \\
\hline Flavonoid & + & + & + \\
Alkaloid & - & - & - \\
Saponin & + & - & + \\
Steroid & - & - & - \\
Triterpenoid & + & + & + \\
\hline
\end{tabular}

Table 2: Antioxidant activities (DPPH method) of yellow velvetleaf fruit (Limnocharis flava) extract

\begin{tabular}{llllll}
\hline Sample & \multicolumn{4}{l}{ \% inhibition } \\
\cline { 2 - 6 } & $\mathbf{5 0} \mathbf{~ p p m}$ & $\mathbf{1 0 0} \mathbf{~ p p m}$ & $\mathbf{2 5 0} \mathbf{~ p p m}$ & $\mathbf{5 0 0} \mathbf{~ p m}$ & $\mathbf{1 0 0 0} \mathbf{~ p m}$ \\
\hline N-hexane & 6.52 & 12.50 & 15.76 & 18.29 & 20.65 \\
Ethyl acetic & 8.15 & 14.31 & 16.31 & 18.84 & 38.77 \\
Methanol & 32.61 & 58.88 & 62.32 & 76.99 & 91.30 \\
\hline
\end{tabular}

DPPH: 2',2'-diphenyl-1-picrylhydrazyl

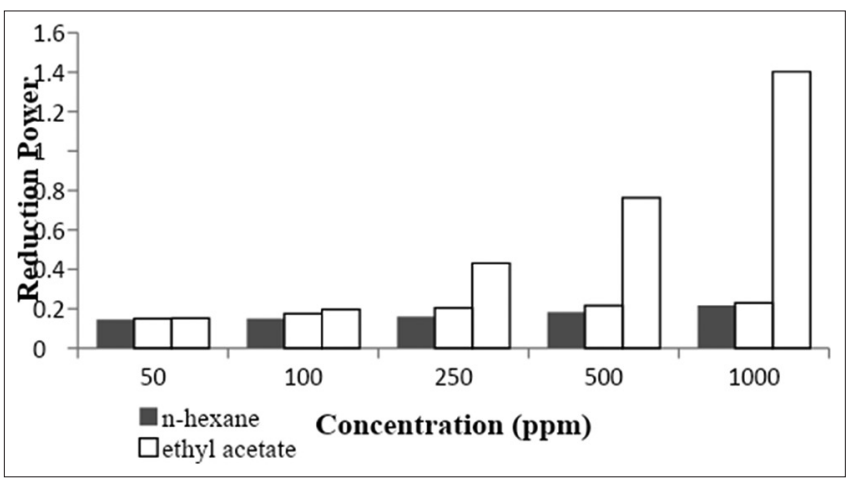

Fig. 1: Reduction power of yellow velvetleaf fruit (Limnocharis flava) extract

which was 0.217 . This value indicates that the methanol extract has the highest ability to reduce that is equal to 1.402 . Increased reduction power in methanol extract along with increasing antioxidant activity and supported by many phytochemical components found in methanol extracts such as flavonoids, saponins, and triterpenoids which can be antioxidant.

\section{CONCLUSION}

Phytochemical result of extracts confirmed the n-hexane extract contained flavonoids, saponins, and terpenoids, while only flavonoids and terpenoids were detected on ethyl acetate extract. Methanol extract has strong antioxidant activity with $\mathrm{IC}_{50}$ value of $96 \mathrm{ppm}$ while ethyl acetate and n-hexane extracts have very weak antioxidant activity with $\mathrm{IC}_{50}$ values $1439.241 \mathrm{ppm}$ and $3321.667 \mathrm{ppm}$. Methanol extract has the highest reduction power at a concentration of $1000 \mathrm{ppm}$, which is equal to 1.402 followed by ethyl acetate extract of 0.229 and n-hexane extract of 0.217 . The best solvent to extract the yellow velvetleaf was methanol.

\section{ACKNOWLEDGMENTS}

This research was supported by Competitive Grant from the Ministry of Research, Technology and Higher Education, the Republic of Indonesia.

\section{AUTHORS' CONTRIBUTIONS}

The author declares that this work was done by the authors named in this article. 


\section{CONFLICTS OF INTEREST}

No conflicts of interest are associated with this work.

\section{REFERENCES}

1. Cheung LM, Cheung PC, Ooi VE. Antioxidant activity and total phenolics of edible mushroom extracts. Food Chem 2003;81:249-55.

2. Inganakal TS, Swamy PL. Evaluation of in vitro antioxidant activity of a triterepne isolated from Madhuca longifolia L leaves. Int J Pharm Pharm Sci 2013;5:389-91.

3. Baehaki A, Widiastuti I, Herpandi, Jannah N. Antioxidant activity of extract of Halodule pinifolia seagrass from solvents with differebt polarities. Orient J Chem 2017;33:181-5.

4. Supriadi A, Baehaki A, Pratama MC. Antibacterial activity of methanol extract from seagrass of Halodule uninervis in the Coastal of Lampung. Der Pharm Lett 2016;8:77-9.

5. Baehaki A, Supriadi A, Pratama MC. Antioxidant activity of methanol extract of Halodule uninervis seagrass from the Coastal of Lampung, Indonesia. Res J Pharm Biol Chem Res 2016;7:1173-77.

6. Baehaki A, Lestari SD, Apriyanti W. Pytochemical screening and antioxidant activity of seed extract of water plant (Nymphaea stellata and Nelumbo nucifera). J Chem Pharm Res 2015;7:221-24.

7. Baehaki A, Herpandi, Putra AA. Antibacterial activity of exttact from swamp plant, Eleocharis dulcis. Orient J Chem 2018;34:573-5.

8. Jacoeb AM, Abdullah A, Rusydi R. Microscopic characteristics and composition of yellow velvetleaf (Limnocharis flava) plants from Situ Gede Bogor. J Sumberdaya Perairan 2010;4:1-6.

9. Abhilash PC, Pandey VC, Srivastava P, Rakesh PS, Chandran S, Singh N, et al. Phytofiltration of cadmium from water by Limnocharis flava (L.) buchenau grown in free-floating culture system. J Hazard Mater 2009;170:791-7.

10. Rusydi R. Potential of yellow velvetleaf (Limnocharis flava) as protein source for fish feed. Acta Aquat 2014;1:36-8.

11. Maisuthisakul P, Pasuk S, Ritthiruangdej P. Relationship between antioxidant properties and chemical composition of some Thai plants. J Food Compost Anal 2008;21:229-40.

12. Harborne JB. Phytochemical Methods. $2^{\text {nd }}$ ed. New York: Chapman and Hall; 1987.

13. Hanani E, Moneim B, Sekarini R. Identification of antioxidant compounds in the sponge Callispongia $\mathrm{sp}$ of the thousand Islands. Magazine Pharm Sci 2005;2:127-33.

14. Middleton E, Kandaswami C, dan Theoharides TC. The effects of plant flavonoids on mammalian cells: Implications for inflammation, heart disease and cancer. Pharmacol Rev 2000;52:673-751.

15. Lotito SB, Fraga CG. Catechins delay lipid oxidation and alphatocopherol and beta-carotene depletion following ascorbate depletion in human plasma. Proc Soc Exp Biol Med 2000;225:32-8.

16. Goldberg G. Plants: Diet and Health. Iowa State, USA: Blackwell Publishing Company; 2003.

17. Trease GE, Evans WC. Pharmalognosy. $14^{\text {th }}$ ed. London: Harcourt Publishers Limited; 2000. 